\title{
Evaluating Mobile Phones and Web Sites for Academic Information Needs
}

\author{
Muhammad Farhan \\ Dept. of Computer Science and IT \\ The Islamia Univ. of Bahawalpur, \\ Pakistan
}

\author{
Malik Muhammad Saad Missen \\ Dept. of Computer Science and IT \\ The Islamia Univ. of Bahawalpur, \\ Pakistan
}

\author{
Nadeem Akhtar \\ Dept. of Computer Science and IT \\ The Islamia Univ. of Bahawalpur, \\ Pakistan
}

Muhammad Ali Nizamani

Faculty of Engineering, Science and Tech

Isra University Haiderabad

\author{
Amnah Firdous \\ Dept. of Computer Science \\ COMSATS Institute of Information \\ Technology
}

Hina Asmat

Dept. of Computer Science

Govt. S.E. College, Bahawalpur

\begin{abstract}
In the last decade, there has been an exponential growth in use of mobile phones among people. Smart phone invention has digitized life of a common man especially after introduction of 3G/4G technology. People are used to use Internet on the move because of this advancement in technology. This advancement has also motivated usability design researchers to propose more usable designs for both smart phones and web sites. This work focuses on evaluation of web usability of mobile phones as well as usability of university web sites. Evaluation is performed on the most popular mobile phones required by the most common mobile users. Selection of the most popular mobile devices, the most common mobile users and their web usage is done by conducting a very detailed survey in the local market. Survey concludes that students and labors are the most common buyers of mobile phones and we choose three mobiles phones from the category of most popular phones that are iPhone (iPhone 4 precisely), Q-Mobile (Q Mobile A35) and Windows phone (Lumia 535). Six participants (three male and three females) are selected for fully detailed and rigorous taskbased usability testing with "think aloud" technique. Task scenarios are defined to evaluate the usability of both i.e. smart phones and chosen university web sites. From results of usability testing, we find out that iPhone has better usability design as far as its response time is concerned while $Q$ Mobile ranks second and Microsoft Windows phone takes last position in this ranking. Usability evaluation of university web sites on these mobile phones concludes that web site of Islamia university of Bahawalpur (I.U.B, Bahawalpur) has better mobile usability design and Bahauddin Zakariya university (BZU, Multan) and NFC Institute of Engineering and Technology NFCIET, Multan) second and third respectively and while web site of Institute of Southern Punjab (ISP, Multan) comes last when measured in terms of task completion time. All tests are performed on wireless network when internet download speed is between 3MBPS to 3.2MBPS.
\end{abstract}

Keywords-Usability Engineering; Smart Phones; Academic information need

\section{INTRODUCTION}

Since the arrival of mobile phones in the 1980s, they have turned out to be broadly utilized among all ages. In fact, they are turning into the personal computers because users are increasingly using mobile phones rather than desktops to get to information and services. Due to this significant diffusion of mobile technologies in our lives, the way we used to access information has also changed. For example, we used to visit schools, colleges or universities or their prospectus for getting information of any kind (like course material, degree programs, directory etc). However with the advancement of technology, all such information lies in your hands if you are benefitting from mobile internet. Accessing academic information is not only a need of a causal user but it becomes mandatory for students to get daily information from their university's web site [16]. Students often consult institute's web site for occasional changes in examination schedules, assignments, course material, exam results, news etc. We know that usability of user interfaces are very important for web sites [17] but it becomes more important issue when a web site is being viewed on a mobile and is being frequently visited by many users.

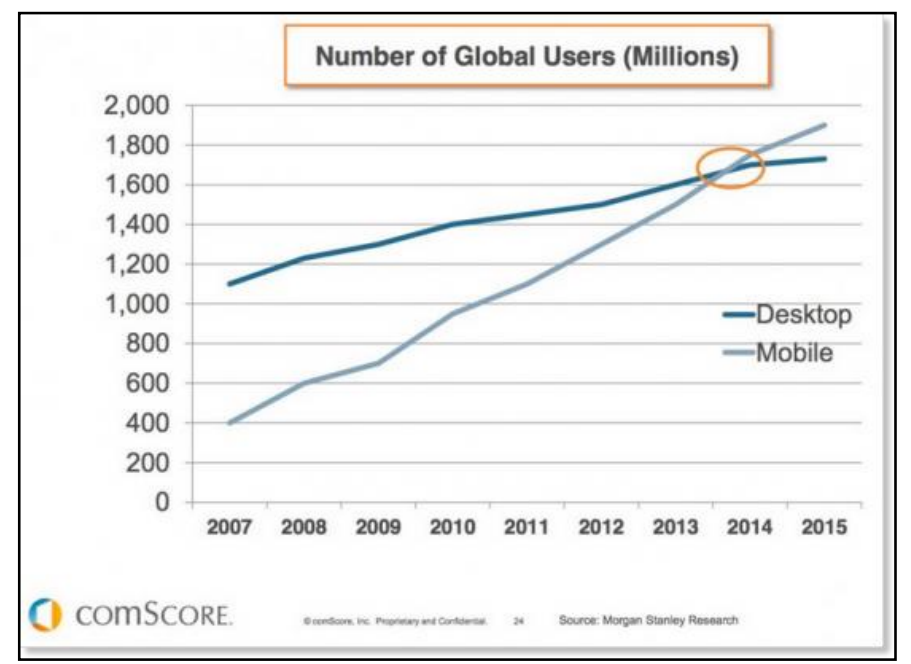


Fig. 1. Mobile Vs Desktop Users1

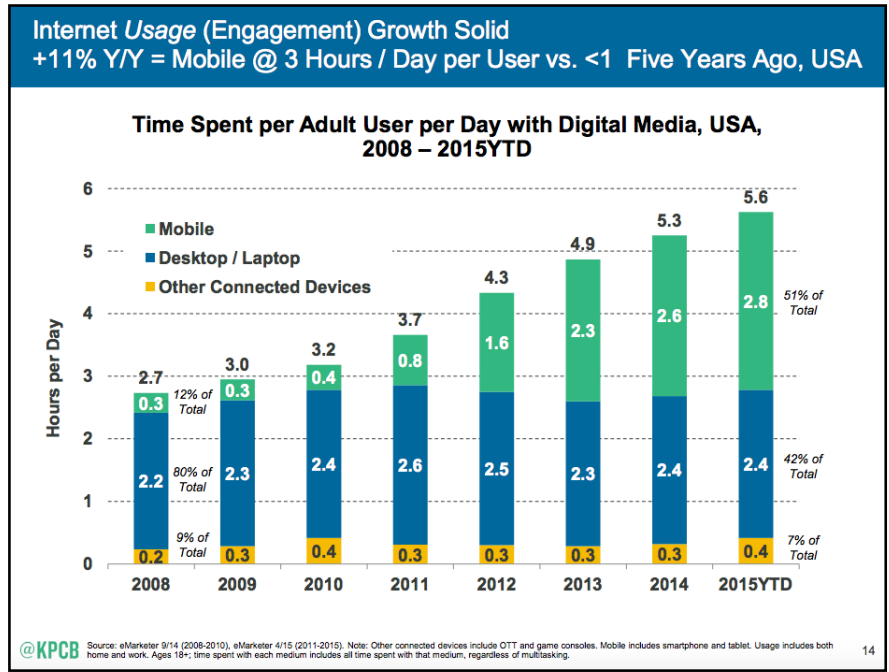

Fig. 2. Internet usage: Mobile Vs Desktop2

\section{Research Objectives}

- To find out what kind of smart phones are popular among students,

- To find out what types of tasks student perform while surfing university web sites,

- To evaluate usability of popular smart phones for defined tasks,

- To evaluate usability of different university web sites.

\section{RELATED WORK}

Our work in this paper basically corresponds to two major issues i.e.

- Usability of mobile web sites

- Usability of mobiles phone interactions,

Therefore, in this section of related work we will discuss the work who have worked on both or one of these aspects.

\section{A. Web Site Usability Evaluation}

Because our work relates to evaluation of university web sites, we mostly highlight work done on university web sites already.

The work done by Jabar et al. [1] focuses on usability elevation of three Malaysian university Websites. Researchers took support of questionnaires for this purpose. The first portion of their questionnaire directs the demographic of the respondents while the second portion combine twenty four questions that were used to evaluate the usability of

1 http://www.smartinsights.com/mobile-marketing/mobile-marketinganalytics/mobile-marketing-statistics/

http://www.smartinsights.com/internet-marketing-statistics/insights-fromkpcb-us-and-global-internet-trends-2015-report/attachment/mobile-internettrends-mary-meeker-2015-1/ educational websites. Overall figure of 351 students were chosen to answer questionnaires for evaluating websites usability depending on Content, organization and readability, navigation and links, user interface layout and performance and efficiency. The result point out the strengths and flaws for each web site evaluated. Similar kind of work was done by Anwar and Keita [2] on Bangladeshi university web sites with a focus on more technical aspects. Their research evaluates some selective university websites in Bangladesh from the usability aspect. Two online automated appliance namely web page analyzer and html toolbox were used along with a questionnaire conducted against users of these websites. These appliance were used to evaluate, download time html code flaw, and scope of the html page. The survey questioner was split into two sections. The first part directs the attribute of member and the second part contains thirty survey questions that were used to assess the usability of some university websites in Bangladesh. It is found out that most of the users are not satisfied by usability of these websites while few of them are satisfied with the accessible attributes. However, there are some flaws in some aspects of the design, interface, and performances. Another work [3] in the same category is found on Nigerian universities web site evaluation. This study performs usability evaluation of ten randomly selected Nigerian universities websites. They take support of automated appliances such as HTML toolbox and web page analyzer for data gathering. The inside characteristic that were taken into review demonstrate entire number of html files, entire size of images, entire number of images, , entire size of external files, as well as Load time, browsers similarity. The finding show that some of universities websites adhered to the laid down threshold values of these characteristic while some are still very much flawed. They found out that no single university adhered to the verge values as provide by the two automated tools used

Another work on university web site evaluation is done by Dr. Ahmet et al. [4] with a slightly different objective of finding impacts of users' demographics on usability. They analyze and evaluate Namık Kemal University (NKU) website and give direction to grow better and more usable web site. The analysis is done by pursuing two various techniques together. First, a few inside participants were individually asked to answer to the online survey questioner. Second, the link to approach the survey questioner was sent to all inside participant through NKU email system. Results acknowledged that some of the demographic part tested, such as gender and web skill, have important impacts on usability approach of separate users. Layla [5] take a very text-book approach for evaluation of three Jordanian web sites. She preferred a heuristic evaluation technique for this purpose and prepared two documents i.e. heuristic guidelines and tasks list. The assessments included testing all pages related to the preferred universities faculties and their corresponding departments. Thirty four (34) specific types of usability problems were determined.

Beside the evaluation of university web sites, there are works that have worked on evaluation of other genre of sites. For example, Walia [6] evaluate the usability features of preferred national libraries websites of Asia with concern to 
their ordinary attributes of website, URL, window title, time and date, navigation, content, graphic and animation. A usability evaluation checklist was layout on the basis of guidelines given by Neilson. Later evaluating the homepage of preferred web sites it was found that the Japan National Library is at position number one among 23 national libraries of Asia and National Library of Maldives at the last position. Similarly another work to be reported is done by Silva [7]. In this work, usability of the library web site of the University of Colombo was measured for its feasibility, profitability and satisfaction through usability testing technique and post-test survey. The study found that general practicality of the library site was $88.69 \%$ while efficiency was 1.35 minutes/task. For the most part, the users were extraordinarily satisfied with the library website. A different but related work is on usability evaluation of online news papers [8]. The major focus of this study is to evaluate online newspaper websites. The outcome of this research is that usability component is almost satisfactory for all Jordanian online newspapers whereas the web content element is average.

Another related but different work was done by ShihPeng Hsu [9]. It was different in a way that it tried to show that how a website with improved usability and effectiveness with the no difficulty of learning and memorizing have a strong control over the buying behavior of customer. This study used experimental questionnaire process to assess the usability in different Shopping Mall websites.

\section{B. Mobile Phone Interaction Usability}

In this sub-section, we highlight some works related to evaluation of mobile phones usability.

Chi-I Hsu et al. [10] perform mobile usability analysis on basis of two smart mobile phone operating system i.e. iOS and Android. The approach used involved observational experiments and user questionnaire. Total 48 participants are asked to perform five different tasks and rate their satisfaction level on each operating system. The researcher finding is overall iPhone operating system is best as compared to android. Ahmed et al [11] perform a similar type of work by asking questions about usability of Android and iOS. They also proposed an integrated model where both iOS and Android applications can be played in same environment. A similar kind of work is performed by Yong $\mathrm{Gu} \mathrm{Ji}$ et al [12] where they used heuristic approach. Patrick M. Finley [13] evaluated and compared the usability of different smart phones for table and list based content.

Kimberly [14] found out how smart phone's hardware and operating system impact the usability of library web sites. He performed pre-test and post test surveys on 12 students of age greater than 18 years old.

Comparing our work with the related work, it can be observed that our work is more focused on university's web sites on popular mobile phones in Pakistan. We perform our experiments in a very systematic way by following the findings of our survey. We perform a detailed usability testing by focusing in minor details to give reliable results.

\section{SURVEY}

This survey is conducted to gather information on 
consumer's mobile phone. Our Survey will give you the information you need so that you can create campaigns and improve your services that are geared toward mobile website. Market research concentrating on any survey-based method delivered via a mobile device and website This includes Apps, SMS, WAP, Location-based Services, Mobile WEB, and both Mobile Terminated and Mobile Originated interactions. Want to ramp up your mobile marketing or improve your cell phone services Send this expert-certified mobile or cell phone survey to get a better understanding of consumer mobile habits. Total round about 100 participant are conduct for survy 50 shopkeapar and 50 customer and the survey questionnaire are given below.

\section{Survey Findings}

It is found that there are three types of most frequent buyers of mobile phones in the market:

- Daily wage workers

- Students

- Common Men

It is also found out that there are three categories of mobile phones most commonly bought:

- First Category:
○ Popular among workers,
○ Loud sound,
- Can play video,
○ Long lasting battery,
- Price range $3 \mathrm{~K}$ to $5 \mathrm{~K}$,
○ Mp 3 Supported.

- Second Category:

- Popular among students,

- Loud sound,

- Can play video,

○ Long lasting battery,

- 3G/4G supported,

○ Price range $3 \mathrm{~K}$ to $10 \mathrm{~K}$.

- Third Category
- Popular among common men,
○ Loud sound,
- Can play video,
○ Long lasting battery,
○ Mp3/Mp4 supported,
○ Price range $3 \mathrm{k}$ to $15 \mathrm{k}$.

\section{USABILITY TESTING}

\section{A. Participant Selection}

In our survey, we find out that three types of different customers of frequent mobile buyers exist in the local market. We choose one category among them i.e. students to continue our experiments. We recruit total 6 participants (03 males and 03 females) for usability testing. All of them are studying in educational institutes of South Punjab. Two belong to distt. Rahim Yar Khan, two belong to Bahawalur while remaining two belong to Multan. All of them are IT Graduates having more than 2 years of experience of using Internet on Smart Phones. The students are financially compensated for their time and participation.

\section{B. Mobile Phone Selection}

Choosing students as our choice of participants, we choose three mobile sets from different companies belonging to the category students mostly buy (see survey in previous section). The mobile specifications are given below:

TABLE I. SELECTED MobiLE SPECIFICATIONS

\begin{tabular}{|c|c|}
\hline 1 & $\begin{array}{l}\text { Microsoft Lumia } 535 \\
\text { Release date :2014 December } \\
\text { LCD Resolution: } 540 \text { x } 960 \\
\text { Camera :5 Mega pixel } \\
\text { Memory :internal } 8 \text { GB RAM } 1 \text { GB } \\
\text { MP3 Function: Support }\end{array}$ \\
\hline 2 & $\begin{array}{l}\text { Q Mobile :A65 } \\
\text { Release date: } 2013 \text { October } \\
\text { LCD Resolution: } 800 \text { x } 400 \\
\text { Camera:3 Mega Pixel } \\
\text { Memory: internal 4GB RAM } 512 \\
\text { MP3 Function :Support }\end{array}$ \\
\hline 3 & $\begin{array}{l}\text { Apple I phone: } 4 \mathrm{~S} \\
\text { Release date:2010 June } \\
\text { LCD Resolution:540*960 } \\
\text { Camer:5 Mega Pixel } \\
\text { Memory: internal } 16 \text { GB 1GB RAM } \\
\text { MP } 3 \text { Function: Support }\end{array}$ \\
\hline
\end{tabular}

\section{Web Site Selection}

Following web sites are selected for usability testing.

TABLE II. SELECTED Web Sites

\begin{tabular}{|l|l|l|}
\hline 1 & $\begin{array}{l}\text { The Islamia Univ. of Bahawalpur } \\
\text { Pakistan }\end{array}$ & http://www.iub.com.pk \\
\hline 2 & $\begin{array}{l}\text { Institute of Southern Punjab, } \\
\text { Multan Pakistan }\end{array}$ & http://www.isp.edu.pk \\
\hline 3 & $\begin{array}{l}\text { Bahaduddin Zakaria Univ. } \\
\text { Multan Pakistan }\end{array}$ & http://www.bzu.edu.pk \\
\hline
\end{tabular}




\begin{tabular}{|l|l|l|}
\hline & & \\
\hline 4 & $\begin{array}{l}\text { NFC Institute of Engineering and } \\
\text { Technology Multan Pakistan }\end{array}$ & http://nfciet.edu.pk/ \\
\hline
\end{tabular}

\section{Evaluation and Results}

Few performed usability evaluation in a very detailed way. Each site is evaluated by each participant on each selected mobile phone. In this way, we performed total 72 usability evaluations. For anonymity, we name test participants as A, $\mathrm{B}, \mathrm{C}, \mathrm{D}, \mathrm{E}$ and $\mathrm{F}$.

\section{- Usability Goals}

TABLE III. WEB USABILITY GoALS

\begin{tabular}{|c|c|c|}
\hline & Goals & Description \\
\hline 1 & Goal 1 & Accessing University web site \\
\hline 2 & Goal 2 & $\begin{array}{l}\text { Accessing the Basic Information about Program and detail } \\
\text { of Syllabus }\end{array}$ \\
\hline 3 & Goal 3 & Information About Facility \\
\hline 4 & Goal 4 & Find fee structure \\
\hline 5 & Goal 5 & Find Available Job In the University \\
\hline 6 & Goal 6 & All Information About University Reflected On Home Page \\
\hline 7 & Goal 7 & Frequently Access Information Available On Single Click \\
\hline 8 & Goal 8 & News and events Section are clearly visible on home page \\
\hline 9 & Goal 9 & Applicable Information Available On Website \\
\hline 10 & $\begin{array}{l}\text { Goal } \\
10\end{array}$ & $\begin{array}{l}\text { Contents is Visible With looking over or without looking } \\
\text { over }\end{array}$ \\
\hline 11 & $\begin{array}{l}\text { Goal } \\
11\end{array}$ & Easygoing client can Find Information with no assistance \\
\hline 12 & $\begin{array}{l}\text { Goal } \\
12\end{array}$ & un necessary stuff available or not \\
\hline 13 & $\begin{array}{l}\text { Goal } \\
13\end{array}$ & $\begin{array}{l}\text { Complete Navigation for client and Search Engine are } \\
\text { accessible }\end{array}$ \\
\hline
\end{tabular}

\section{- Usability Goals to Usability Task Conversion}

It is a general practice to convert the defined usability goals into actions or tasks [15]. Table IV shows defined goals and equivalent tasks defined for our experiments.

TABLE IV. GOAL TO TASK CONVERSION

\begin{tabular}{|l|l|l|}
\hline & Goals & Corresponding Task \\
\hline 1 & Goal 1 & $\begin{array}{l}\text { Open index page of web site of the Institute of Southern } \\
\text { Punjab }\end{array}$ \\
\hline 2 & Goal 2 & Get the detail of the admission criteria of computer science \\
\hline 3 & Goal 3 & $\begin{array}{l}\text { Find the Syllabus of BS(Cs)\&BS(IT) and compare } \\
\text { it(Explanation }\end{array}$ \\
\hline 4 & Goal 4 & Check the Profiles of P.H.D professor in computer Science \\
\hline 5 & Goal 5 & Find Fee Structure of BS (Cs) \$BS (IT)program \\
\hline 6 & Goal 6 & $\begin{array}{l}\text { Check the Different Categories are Provided and Clearly } \\
\text { Visible on the homepage( Explanation } \rightarrow \text { About Iub } \\
\rightarrow \text { Administration } \rightarrow \text { Academics } \rightarrow\end{array}$ \\
\hline
\end{tabular}

\begin{tabular}{|l|l|l|}
\hline & & Facilities $\rightarrow$ Admission $\rightarrow$,Research $\rightarrow$ Alumni, \\
\hline 7 & Goal 7 & $\begin{array}{l}\text { Useful Content is Presented on the Home Page or within } \\
\text { one click of the home page.(Explanation to check on one } \\
\text { click all link are open and visible Like notification, result } \\
\text { etc) }\end{array}$ \\
\hline 8 & Goal 8 & $\begin{array}{l}\text { Recently Uploaded Features are Displayed in efficient like } \\
\text { News, Notification and updates link. }\end{array}$ \\
\hline 9 & Goal 9 & $\begin{array}{l}\text { Check this Site is Free From Irrelevant, Unnecessary and } \\
\text { Distracting Information }\end{array}$ \\
\hline 10 & $\begin{array}{l}\text { Goal } \\
10\end{array}$ & $\begin{array}{l}\text { The Site Requires Minimal Scrolling and Clicking } \\
\text { (Explanation open website do you required scrolling to } \\
\text { view all the content ) }\end{array}$ \\
\hline 11 & $\begin{array}{l}\text { Goal } \\
11\end{array}$ & $\begin{array}{l}\text { A Typical First-Time Visitor can do the most Common } \\
\text { tasks without assistance. }\end{array}$ \\
\hline 12 & $\begin{array}{l}\text { Goal } \\
12\end{array}$ & $\begin{array}{l}\text { Unwanted Features (e.g. Flash animations) can be stopped } \\
\text { or skipped }\end{array}$ \\
\hline 13 & $\begin{array}{l}\text { Goal } \\
13\end{array}$ & $\begin{array}{l}\text { Check Site map that provides an overview of the site's } \\
\text { content.(Explanation you search like keyword for e. g you } \\
\text { just click on site map and search keyword like job ,home, } \\
\text { contact, etc) }\end{array}$ \\
\hline
\end{tabular}

In table $\mathrm{V}$, we describe an example of the evaluation that is performed by each user for each mobile and for each site. Each user is closely observed during each defined task and task completion time is also noted. It is to be notified that we perform open time experiments i.e. there is no limit on time and hence a user can continue till the completion of a task.

TABLE V. EXAMPLE OF AN EVALUATION

\begin{tabular}{|c|c|c|c|}
\hline $\begin{array}{l}\text { Goal } \\
\text { No. }\end{array}$ & Task & Observation & $\begin{array}{l}\text { Duration } \\
\text { (hh.min.sec) }\end{array}$ \\
\hline 1 & $\begin{array}{l}\text { Open index page of web site } \\
\text { of the NFC Institute of } \\
\text { Engineering and } \\
\text { Technology }\end{array}$ & $\begin{array}{l}\text { Successfully } \\
\text { open but it take } \\
\text { much more time } \\
\text { for Loading }\end{array}$ & 00:01:03 \\
\hline 2 & $\begin{array}{l}\text { Get the detail of the } \\
\text { admission criteria of } \\
\text { computer science }\end{array}$ & $\begin{array}{l}\text { Admission } \\
\text { criteria find } \\
\text { Successfully }\end{array}$ & 00:00:05 \\
\hline 3 & $\begin{array}{l}\text { Find the Syllabus of } \\
\text { BS(Cs)\&BS(IT) program }\end{array}$ & $\begin{array}{l}\text { Page are loaded } \\
\text { successfully but } \\
\text { content are not } \\
\text { available } \\
\end{array}$ & 00:00:07 \\
\hline 4 & $\begin{array}{l}\text { Check the Profiles of } \mathrm{PhD} \\
\text { professor in computer } \\
\text { Science }\end{array}$ & $\begin{array}{l}\text { Profile found } \\
\text { successfully but } \\
\text { content are not } \\
\text { showing }\end{array}$ & 00:00:16 \\
\hline 5 & $\begin{array}{l}\text { Find Fee Structure of BS } \\
\text { (Cs) \$BS (IT)program }\end{array}$ & $\begin{array}{l}\text { Fee Structure of } \\
\text { BS (Cs) \$BS } \\
\text { (IT)program } \\
\text { Find } \\
\text { Successfully }\end{array}$ & 00:00:19 \\
\hline 6 & check the available job & $\begin{array}{l}\text { Available job } \\
\text { found } \\
\text { successfully }\end{array}$ & 00:00:11 \\
\hline 7 & $\begin{array}{l}\text { Open index page of web site } \\
\text { of the NFC Institute of } \\
\text { Engineering and } \\
\text { Technology }\end{array}$ & $\begin{array}{l}\text { Successfully } \\
\text { open but it take } \\
\text { much more time } \\
\text { for Loading }\end{array}$ & 00:01:03 \\
\hline 8 & $\begin{array}{l}\text { Get the detail of the } \\
\text { admission criteria of } \\
\text { computer science }\end{array}$ & $\begin{array}{l}\text { Admission } \\
\text { criteria find } \\
\text { Successfully }\end{array}$ & 00:00:05 \\
\hline 9 & $\begin{array}{l}\text { Find the Syllabus of } \\
\text { BS(Cs)\&BS(IT) program }\end{array}$ & $\begin{array}{l}\text { Page are loaded } \\
\text { successfully but }\end{array}$ & 00:00:07 \\
\hline
\end{tabular}




\begin{tabular}{|c|c|c|c|}
\hline & & $\begin{array}{l}\text { content are not } \\
\text { available }\end{array}$ & \\
\hline 10 & $\begin{array}{l}\text { Check the Profiles of p.h.d } \\
\text { professor in computer } \\
\text { Science }\end{array}$ & $\begin{array}{l}\text { Profile found } \\
\text { successfully but } \\
\text { content are not } \\
\text { showing }\end{array}$ & 00:00:16 \\
\hline 11 & $\begin{array}{l}\text { Find Fee Structure of BS } \\
\text { (Cs) \$BS (IT)program }\end{array}$ & $\begin{array}{l}\text { Fee Structure of } \\
\text { BS (Cs) \$BS } \\
\text { (IT)program } \\
\text { Find } \\
\text { Successfully }\end{array}$ & 00:00:19 \\
\hline 12 & check the available job & $\begin{array}{l}\text { Available job } \\
\text { found } \\
\text { successfully }\end{array}$ & 00:00:11 \\
\hline 13 & $\begin{array}{l}\text { Open index page of web site } \\
\text { of the NFC Institute of } \\
\text { Engineering and } \\
\text { Technology }\end{array}$ & $\begin{array}{l}\text { Successfully } \\
\text { open but it take } \\
\text { much more time } \\
\text { for Loading }\end{array}$ & 00:01:03 \\
\hline
\end{tabular}

Once we have results for all the experiments, Table VI-A and table VI-B describe the results for web site of Bahauddin Zakaria University Multan for all the defined tasks. Due to space limitations, tables of all results cannot be mentioned here. Looking at the results, we can see few interesting patterns like it is obvious that open web site task is taking too much time for all mobile phones. Similar is the case for downloading a file. There are very strong and obvious reasons behind these results which is speed of Internet being used while performing experiments. This is the reason we performed all experiments on the same network. If we look at overall results, it can be concluded that apparently mobile phones interfaces and web site interfaces are providing acceptable usable interfaces; however problems are being caused by Wifi speed apparently. We will have a detailed look at mobile interfaces and web sites usability following in subsections. 
TABLE VI. A: TASK BASED Time STATISTICS (IN SECONDS) - PART I

\begin{tabular}{|l|l|l|l|l|l|l|l|l|}
\hline & $\begin{array}{l}\text { Login } \\
\text { Time }\end{array}$ & $\begin{array}{l}\text { Connect } \\
\text { with } \\
\text { WIFI }\end{array}$ & $\begin{array}{l}\text { Open } \\
\text { Browser }\end{array}$ & $\begin{array}{l}\text { Open } \\
\text { Web Site }\end{array}$ & $\begin{array}{l}\text { Open } \\
\text { multiple } \\
\text { page at a } \\
\text { time }\end{array}$ & $\begin{array}{l}\text { Close } \\
\text { all } \\
\text { tabs } \\
\text { time }\end{array}$ & $\begin{array}{l}\text { Download } \\
\text { Any file }\end{array}$ & $\begin{array}{l}\text { Save } \\
\text { bookmark }\end{array}$ \\
\hline Mean & 1.44 & 3.10 & 3.01 & 18.29 & 11.38 & 4.56 & 24.18 & 6.43 \\
\hline $\begin{array}{l}\text { Std. Mean of } \\
\text { Error }\end{array}$ & 0.09 & 0.19 & 0.15 & 4.02 & 0.85 & 0.36 & 1.10 & 0.66 \\
\hline Median & 1.35 & 2.67 & 2.78 & 3.94 & 9.31 & 3.85 & 22.31 & 4.29 \\
\hline Mode & 1 & 2 & 3 & 3 & 5 & 2 & 22 & 3 \\
\hline $\begin{array}{l}\text { Std. } \\
\text { Deviation }\end{array}$ & 0.76 & 1.68 & 1.30 & 34.16 & 7.23 & 3.11 & 9.33 & 5.59 \\
\hline Variance & 0.58 & 2.85 & 1.70 & 1167.39 & 52.33 & 9.71 & 87.19 & 31.31 \\
\hline Range & 3 & 8 & 7 & 148 & 32 & 21 & 45 & 27 \\
\hline Minimum & 1 & 1 & 1 & 1 & 5 & 1 & 2 & 2 \\
\hline Maximum & 4 & 9 & 8 & 149 & 37 & 22 & 47 & 29 \\
\hline Sum & 104 & 223 & 217 & 1317 & 819 & 328 & 1741 \\
\hline
\end{tabular}

TABLE VI. B: TASK BaSed Time Statistics (IN SECONDS) - PART II

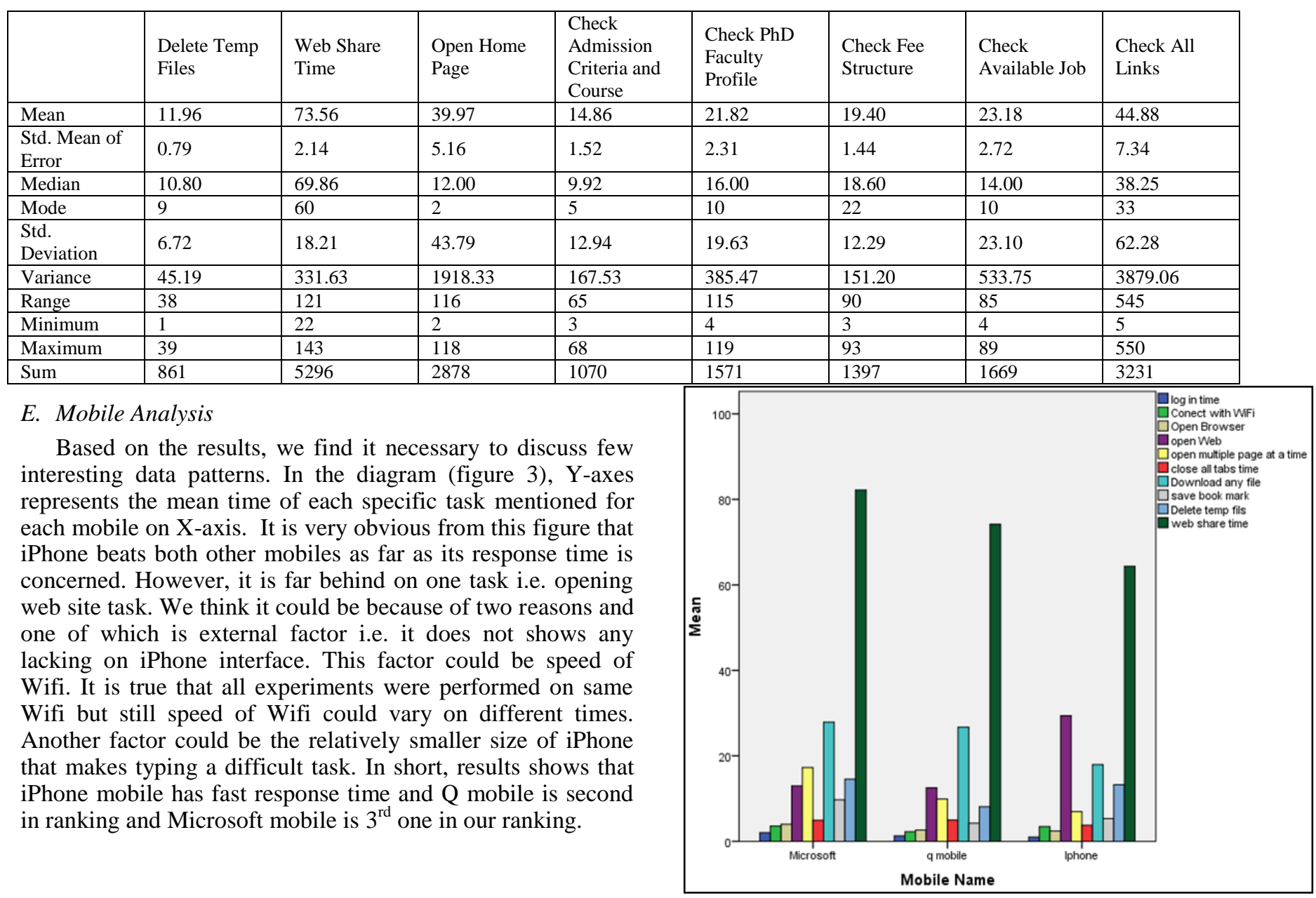

Fig. 3. Web Site Usability Task Based comparison of Mobile Phones 


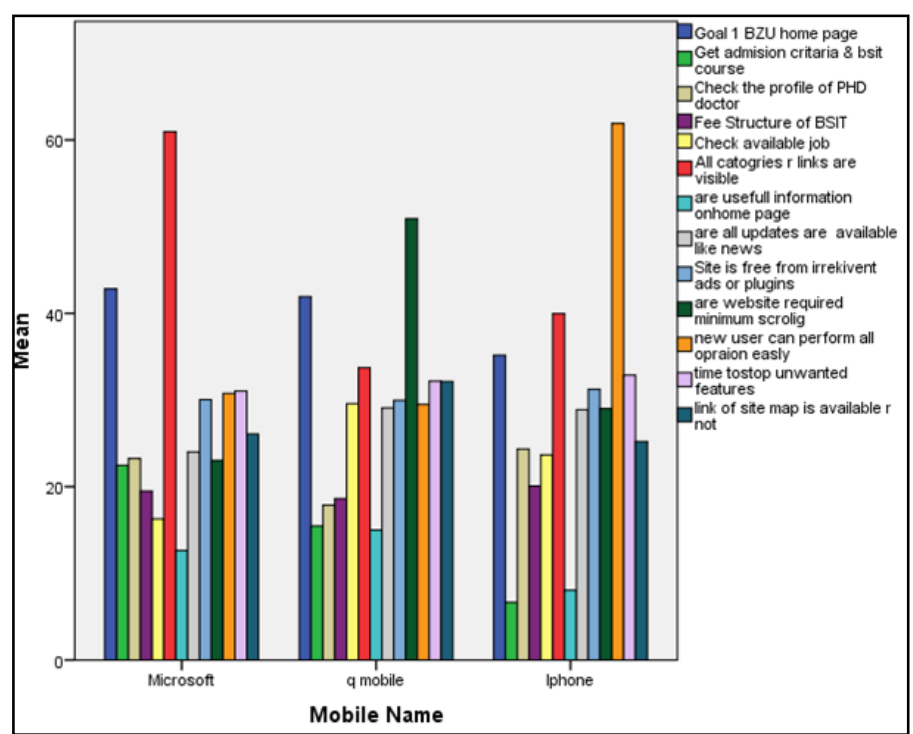

Fig. 4. Mobile Interface Task Based comparison of Mobile Phones

In figure 4 we give thirteen goals to the different users after giving some training that how the different tasks are performed. In this figure, each color represents a different task. A short description of the task is given on right side of the graph. From this histogram, we can easily conclude that over all response time of iPhone mobile performance or response time is also better on average i.e. it is faster due to its simplicity of user interface. On the other hand Q mobile is second fastest mobile in our ranking while Microsoft mobile stands itself on last in our experiments as far as time to complete tasks on these mobile phones is concerned.

\section{F. Gender Based Analysis}

In our case study the performance of both males and females are mostly similar because of in our study we take both male and females are educated in IT so that's why the reason of computational capability is same and all goals are related to educational website so there all the information on all websites are same just position of different information is change which is not difficult to trace both of them in our results male are little bit better than female due to experience.

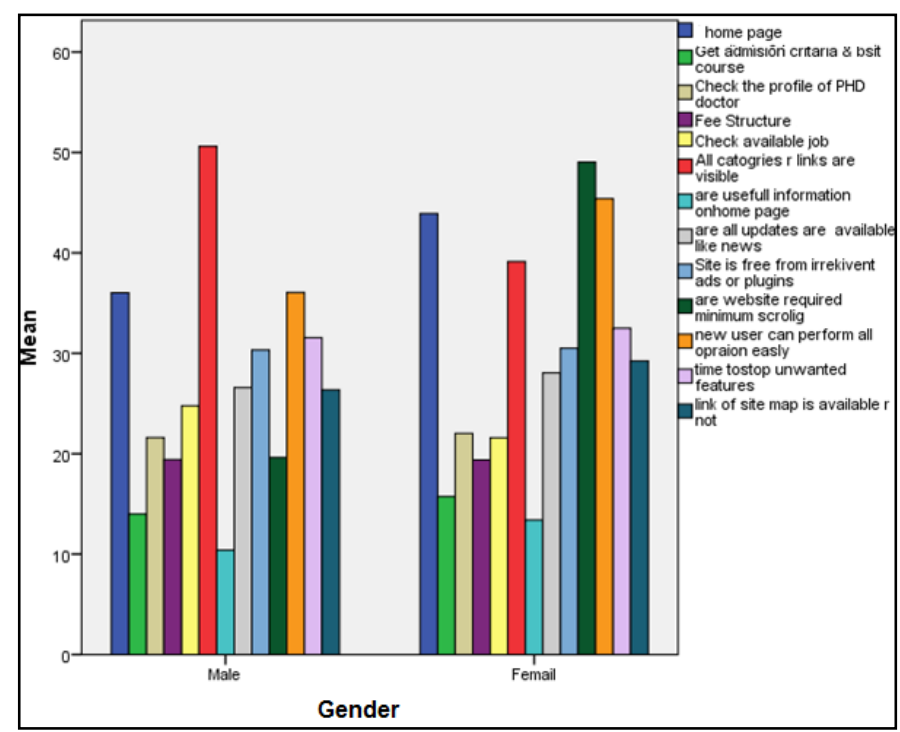

Fig. 5. Gender Based comparison of Task Times

But when we compare the results of male and female participants for evaluation of mobile interfaces (figure 6), it can be concluded that males perform slightly better than females. To find the reasons behind this slight difference, we concluded the pre-test questionnaire filled by each participant and it is found out that males are used to spend more hours on mobiles than females in their free time. Hence, males are more used to perform these operations on mobiles and this is what results are reflecting.

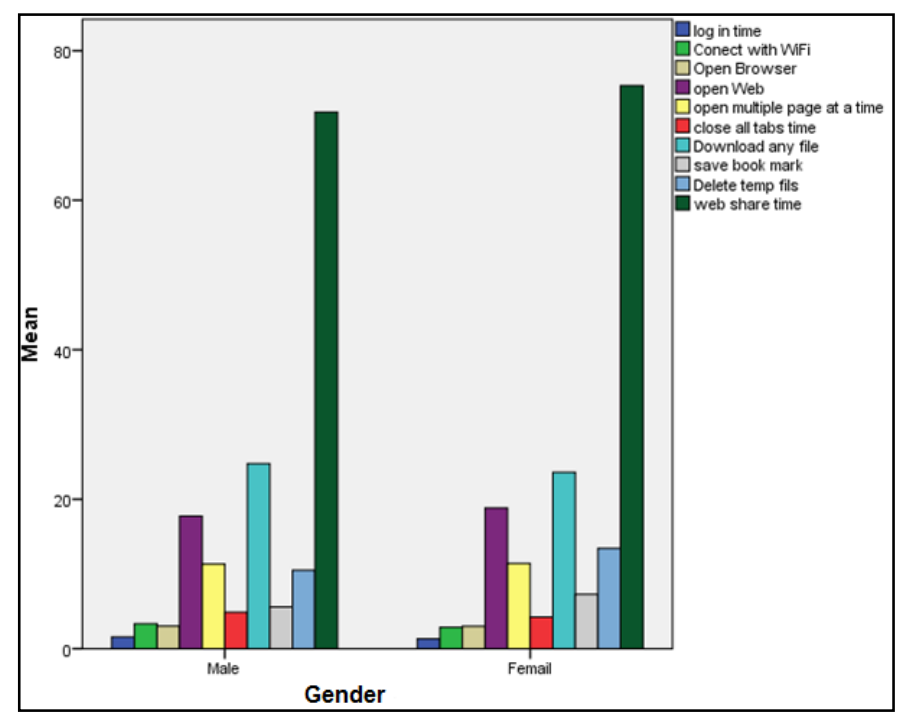

Fig. 6. Gender Based Task Comparisons on Phone Interface 


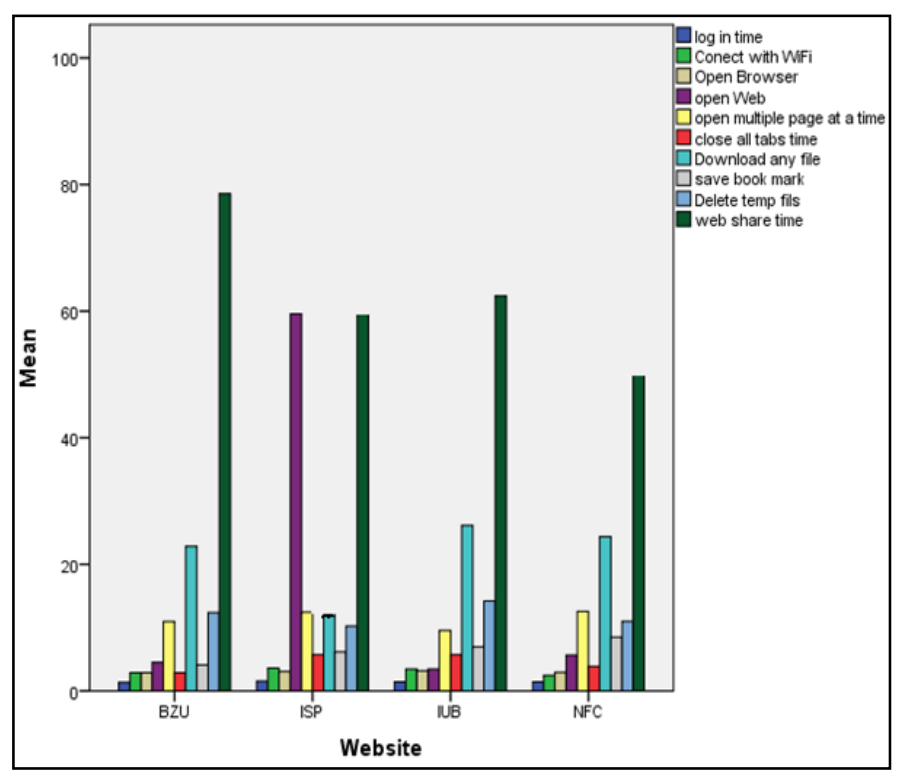

Fig. 7. Comparison of Web Sites Task Based Usability

Figure 7 shows the website analysis to conclude that which web site is better in its usability interface. As shown, Y-axis represents the mean time taken to complete tasks on the web sites mentioned on $\mathrm{X}$-axis of the figure. With respect to completion time, we can conclude from given histogram that NFCEIT has the best user interface among the set of given web sites. Rests of the web sites are almost same with slight differences on different tasks.

\section{CONLUSIONS}

This research study focused on very important task of usability engineering where we have evaluated university web sites as far as smart phones for their usability. We know that inaccessibility of information means absence of information which makes a very important thesis for this work. The methodology for this work includes a detailed survey and usability testing. Survey findings reveals the types of most frequent buyer of phones and also the types of the most popular phones among these frequent buyers. Further, we performed a set of 72 usability tests to conclude which smart phones and web sites have better usability interfaces. We also analyzed the results with respect to gender and task performed. We conclude that male perform better than females because they are used to use spend more time on mobile phones. Similarly, it was found out that iPhone has a better usability interface than other smart phones while NFCEIT web site is better from other sites. The conclusions of our experiments are listed below:

- Three most frequent mobile phones buyers are labors, students and rest of the buyers.

- Three types of most commonly bought mobile phones along with their characteristics (see table I).
- iPhone has a better usability interface than other mobile phone used in our experiments.

- NFCEIT web site has a much better interface than rest of the sites.

- The most difficult tasks to perform are downloading files and opening multiple pages at a time on mobile phones.

- Males are better mobile phone users than females.

\section{REFERENCES}

[1] Jabar, M. A., Usman Abbas Usman, and F. Sidi. "Usability Evaluation of Universities' Websites." International Journal of Information Processing and Management 5.1 (2014): 10.

[2] Islam, Anwarul, and Keita Tsuji. "Evaluation of usage of university websites in Bangladesh." DESIDOC Journal of Library \& Information Technology 31.6 (2011).

[3] Kiyea, Celinus, and Aminat Bolatito Yusuf. "Usibility Evaluation of some Selected Nigerian Universities' Websites." International Journal of Computer Applications 104.3 (2014).

[4] Mentes, S. Ahmet, and Aykut H. Turan. "Assessing the usability of university websites: an empirical study on Namik Kemal University." TOJET: The Turkish Online Journal of Educational Technology 11.3 (2012)..

[5] Hasan, Layla. "Heuristic Evaluation of Three Jordanian University Websites." Informatics in Education 12.2 (2013): 231-251.

[6] Walia, Paramjeet K., and Monika Gupta. "Usability analysis of Homepage of Websites of National Libraries in Asia." Library Philosophy \& Practice (2013).

[7] Silva, M. A. L., and I. D. A. L. Wijayaratne. "Usability evaluation of University of Colombo library website: A case study." Annals of Library and Information Studies (ALIS) 62.1 (2015): 40-47.

[8] Al-Radaideh, Qasem A., et al. "Usability Evaluation of Online News Websites: A User Perspective Approach." International Journal of Human and Social Sciences 6.2 (2011).

[9] Hsu, Shih-Peng, et al. "Usability Evaluation of Mobile Commerce Website on Internet-An empirical study." WHICEB. 2014.

[10] Hsu, Chi-I., Chaochang Chiu, and Wen-Lin Hsu. "USABILITY EVALUATION AND CORRESPONDENCE ANALYSIS OF SMARTPHONE OPERATING SYSTEMS.".

[11] Ahmad, Naseer, Muhammad Waqas Boota, and Abdul Hye Masoom. "Smart phone application evaluation with usability testing approach." Journal of Software Engineering and Applications 7.12 (2014): 1045.

[12] Ji, Yong Gu, et al. "A usability checklist for the usability evaluation of mobile phone user interface." International Journal of HumanComputer Interaction20.3 (2006): 207-231.

[13] Finley, Patrick M. "A study comparing table-based and list-based smartphone interface usability." (2013).

[14] Pendell, Kimberly D., and Michael S. Bowman. "Usability study of a library's mobile website: an example from Portland State University." Information Technology and Libraries (Online) 31.2 (2012): 45.

[15] Kaufman, David R., et al. "Usability in the real world: assessing medical information technologies in patients' homes." Journal of biomedical informatics 36.1 (2003): 45-60.

[16] Zhang, Dongsong, and Boonlit Adipat. "Challenges, methodologies, and issues in the usability testing of mobile applications." International Journal of Human-Computer Interaction 18.3 (2005): 293-308.

[17] Dix, Alan. Human-computer interaction. Springer US, 2009. 